\title{
Teaching the History of Science and Technology
}

This department is especially concerned with educational problems at the undergraduate level. and the training of graduate students for undergraduate tearhing. Articless may discuss theoretical aspects of tearhing. describe the use of experiments and practical aids. or survey a substantial range of educational techniques. Personal reports on smallscale tearhing projects will not normally be arcepted.

\section{Teaching the history of medicine, science and technology in the Federal Republic of Germany and in West Berlin}

\author{
('Hristoph Meinel. Institut für Geschichte der Naturwissenschaften, Mathematik und \\ Technik. Bundesstraße 5.5. D-2000 Hamburg 13, West Germany
}

Received 19 March 1979

\begin{abstract}
Summary
History of medicine is taught in West Germany as part of the standard course offerings for medical students and is well represented at many universities. But history of science and technology unfortunately still lacks any adequate supporting system and accordingly barely continues to survive at a few institutions of the Federal Republic. Although history of medicine serves a different function than history of science and technology. closer cooperation between these groups is possible and greatly desired for the future.
\end{abstract}

1. Introduction. The history of medicine, and to some extent the history of science and technology in Germany can look back at a remarkably long academic tradition. The first chair in the history of medicine was given to Karl Sudhoff at the University of Leipzig in 1905. After the last war. the discipline on the whole has received institutional support on a much wider scale and now occupies a place in at least one of its aspects at almost all of the older universities. Yet within the English-speaking world little seems to be known about how and where these subjects are taught in West Germany. The language barrier can be held only partly responsible for this. It is admittedly difficult to get reliable information from outside. all the more so as the German university system underwent major structural changes in the last few years.

The aim of the present survey is to provide some basic information that might stimulate international cooperation, exchange of scholars and students, and further mutual understanding. Therefore it seems useful to include a list of relevant institutions. to mention a portion of their teaching staff, and to indicate whether their libraries can offer special areas of expertise. It is not intended, however. to specify the diversity of research interests unless they relate directly to teaching programmes. Thus a few institutions devoted purely to research are omitted. The survey will be restricted to both the history of medicine and the history of natural 
sciences and technology, excluding other disciplines which might be covered by the much wider German term Wissenschaftsgeschichte. Philosophy of science as well as sociology of science are dealt with only if they are taught in a historical context.

This survey is partly based upon a questionnaire sent to all universities in the Federal Republic and West Berlin, more than two thirds of which kindly replied. Missing information was obtained from the 1978/79 university calendars. Thus the paper represents the situation as of the end of 1978 .

2. The general situation. Circumstances at present do not seem to be particularly favourable to further growth either in the history of medicine or in the history of science and technology. Even traditional history itself has to defend its territory. Large numbers of students, the tendency towards mass subjects, and growing financial difficulties tend to jeopardize a discipline such as this rather more than a better established one. Nevertheless, the general situation is not altogether unfavourable, in some cases particularly in the history of medicine even remarkably good. But this differs considerably from institute to institute. On the whole, possibilities for research at both junior and senior levels are fairly good, due partly to research grants which are available.

Since 1976 the Stiftung Volkswagenwerk, an industrial foundation, sponsors research projects in the history of medicine, science and technology at a cost equivalent to $£ 4.5$ million pounds sterling. Furthermore, the reorganisation of most universities in the early 1970 s created some new professorships, so that a broad spectrum of research interests and teaching specialities has emerged. As a consequence, a number of other academic positions have disappeared, since financial pressure tends to be fatal to smaller disciplines not in the main line of study. The actual institutional weakness and uncertainty, especially in the history of science and technology, becomes apparent every time a vacant position is to be filled. There is always a danger that even famous chairs might be given to other disciplines; for example, in Frankfurt where the former history of medicine chair has disappeared without any replacement. A complicated and slow process of administration can delay new appointments enormously, as has happened in Berlin where the chair at the Technical University has been vacant since April 1975, but is hopefully to be filled in 1979. Such discontinuity in teaching is of course a major risk for any discipline but fatal for an unestablished one.

The way that the history of medicine on the one hand, and the history of science and technology on the other hand, are taught reflects differences between the German and the British or American university systems. Survey courses over the whole of the history of science at the undergraduate level are given less frequently. Sometimes lectures on the history of a particular science are offered as part of a science curriculum. The usual pattern, however, is a more specialised study at an advanced level which eventually leads to a research project. The history of science is restrictedly dealt with in science faculties or departments, whereas the history of medicine is a general feature of medical faculties. Joint courses and cooperation in teaching even with historians are still rather exceptional partly due to the departmental structure. Traditional 'academic freedom' offers the student an opportunity to take part in such historical courses no matter to which department he belongs, but he makes far less use of this opportunity than one might expect. So it is still difficult to attract students of history, theology and sociology, to mention only a few fields, to history of science classes. Most participants come from a medical or scientific training; but it should be added that even here only a small minority of undergraduates can be won over unless the history of their discipline is a compulsory part of their training or is offered as an option in their examinations. This problem 
even exists in history of medicine, where historical courses are part of the standard offerings compulsory for medical students.

During the last few years there seems to be an awakening interest in history of science and medicine within history departments; and historians of medicine and science for their part are gaining ground on traditionally historical areas of intellectual, economic and social history. So in October 1978 the German Historikertag was held under the motto 'Wissenschaft as a problem of universal history', and for the first time the programme included aspects of the history of medicine and science. However, it will take some time and a great deal of support before history of science can be incorporated into school curricula via the traditional training of historians, as would be wished. Still, the first steps have been taken, as exemplified by a chair for the history of technology at the teachers training college in Schwäbisch Gmünd; while at the universities of Hamburg and Oldenburg history of science forms part of the regular training of student-teachers in science and mathematics.

3. Course of study. It is not easy to make general statements about these rather different approaches. The relatively well institutionalized history of medicine and the history of pharmacy form a compulsory part of the medical, dental, and pharmaceutical curricula, and are taught at undergraduate as well as graduate level. The history of science, on the other hand, is offered usually as a postgraduate study which leads to an advanced degree, supplemented by a few optional lectures for science students. The incorporation of the history of science into science curricula still is exceptional. The history of technology is often taught by social or economic historians within history departments and to students of history. Unfortunately, institutional barriers often impede cooperation and exchange of students between these three courses of study.

Thus, as far as the choice of topics and the academic level are concerned, most teaching is intended for postgraduate study; since the Doctor (Dr. med., Dr. rer. nat., Dr. phil.) in almost all cases is the only degree that can be taken in history of science or medicine. Consequently such students usually are required to have finished a full course of study in medicine or in any one science (4-5 years) before they devote themselves to its history.

What is offered in the doctoral programme naturally depends very much upon individual interests, research topics and the available institutional staff. Most departments have an introductory lecture of 1 to 2 hours a week during 2 to 4 semesters, supplemented by specialised courses on particular subjects. In addition, participation in two or more seminars over two semesters is usual. Frequently these seminars are dedicated to very specific themes and follow the concept of 'exemplary learning'. At the same time they are intended to introduce students into methods of scholarly research, and frequently they are linked to a current research area within the institution. Sometimes the methodology of historical research, handling and tracing of source material, and access to secondary literature are dealt with in a separate seminar. In addition, some institutes strongly recommend that their students take part in lectures and seminars offered by other departments, depending on the student's interest, ability and proposed subject of research. Economic and social history, and auxiliary historical sciences such as palaeography, medieval Latin and other similar subjects are frequently attended.

Most curricula for the doctoral study assume that the required courses can be completed within two or three semesters. Meanwhile, the student chooses a topic for his dissertation in agreement with his supervising Doktorvater. Usually it takes about two years to write the dissertation, though there is no time limit and, especially with part-time students, it often will take considerably longer. Doctoral promotion in any 
case requires a written thesis submitted to the faculty or department. The regulations about required subjects and procedure may differ in detail from one university to another. In general the oral doctoral examination (Rigorosum) takes place either as a public defence of one's own thesis, or as a one-hour examination in history of medicine or science plus half-hour examinations in optional subjects, of which one usually is taken from science, the other from history.

It is worth noting that every doctoral thesis has to be published and consequently should be available through interlibrary loan. As a whole these theses represent a valuable source of information for historians of medicine, and historians of science and technology. These documents of current research are far too seldom known and used abroad. Besides the Annual Index to German Theses, the Nachrichtenblatt of the German Society of the History of Medicine, Science and Technology contains annual lists of doctoral theses completed or in progress.

4. New developments. Recently there have been discussions as to whether one should create courses of studies and other degrees in history of science and technology as an alternative to the doctorate usually available only after a long and specialized scientific training. There is no equivalent problem in the history of medicine. Frequently the counter-argument is heard that only a sound scientific or technical education provides the expertise necessary to understand science and technology in their historical context. The technical universities at Stuttgart and Berlin, however, have created a new M.A. degree in history of science and technology, although even there a full scientific or technical training is strongly recommended as a basic requirement. Nevertheless, as an academic degree, the M.A. is hardly attractive and has never been popular, since it has to compete with the corresponding State Examination which gives the right to teach in schools.

If, therefore, improvements in the teaching possibilities for the history of science and technology are to be expected in the future, it seems more likely that studentteachers in sciences and mathematics at universities will be given an opportunity to take history of science as an option in their State Examination or as a subject in their examination thesis. In the long term prospect it would stimulate the discipline as a whole quite a lot if it gradually became part of the teaching in schools. Promising steps towards that goal have been made recently in various universities: at Bochum (history of geography), Hamburg (history of chemistry and biology), Mainz (history of mathematics, physics and chemistry), Marburg (history of biology) and Oldenburg (history of mathematics). Furthermore, some universities offer history of science as an option in their Diplom curricula in particular sciences (4-5 years).

Although not really new, it might be worth mentioning here that there are annual meetings of lecturers, assistants, Doktoranden and students of the history of medicine, science and technology, called 'the Driburger Kreis.' These meetings are intended to provide opportunities to present the results of recently completed theses, or to discuss work in progress.

5. Outline of possibilities for study. History of medicine is a compulsory subject for all students of medioine and dentistry during the pre-clinical, under-graduate, part of their training, and it forms part of the first medical State Examination. Teaching usually consists of one introductory lecture a week on the general history of medicine. In addition, institutes for the history of medicine offer courses on medical terminology which are compulsory for medical students and often contain historical aspects, as well as an introduction to medical bibliography. For advanced students and those who wish to do research work in history of medicine more specialised lectures and seminars are offered during the clinical part of their training. Independent institutes for the history of medicine exist in nearly every medical 
faculty. Some of them also devote a substantial amount of their teaching to the general history of science and more especially to the history of biology. The doctorate in history of medicine also requires the medical or dental State Examination. Since almost all medical students and many students of dentistry take the M.D. by research, the number of students in history of medicine is relatively very high. At the 16 institutes for the history of medicine that returned the questionnaire, more than 150 doctoral dissertations had been completed during 1976-77 alone! For students of veterinary medicine there are opportunities to study the history of their subject in Hannover.

The history of pharmacy is a compulsory subject for all students of pharmacy and forms part of the pharmaceutical State Examination. Teaching usually is based upon introductory lectures on the history of science over several semesters, with special regard to pharmacy, supplemented by courses on pharmaceutical terminology, lectures on the pharmaceutical profession and professional deontology, all of which often exhibit historical aspects. There are separate units for the history of pharmacy at Brunswick and Marburg; at other universities the discipline is taught by visiting lecturers. The pharmaceutical State Examination or Diplom plus attendance at lectures and seminars for at least two semesters as a full time student is necessary to obtain the doctorate. Additional courses in general history are also strongly recommended or even compulsory.

The history of science, mathematics and technology is optional, and can be studied at a number of different institutions, including the few institutes specializing in the history of science and technology, as well as institutes for the history of pharmacy, and some institutes for the history of medicine, especially for history of biology. A few history departments teach the history of technology. Only at Berlin, Regensburg and Stuttgart are there M.A. courses in the history of science and technology, which include teaching in general history, mathematics, sciences, engineering, economics and social sciences. A previous training in science or engineering is recommended. In general, however, the subject is chosen after a full training in science or mathematics (4-5 years), finished with either Diplom or State Examination, and eventually leads to the doctorate. Usually at least two semesters of full-time study, attendance at specialized lectures and seminars, and additional courses in history are required. A speciality at Bochum and Bonn is the history of geography, which is taught mainly to students of geography. But such a natural student clientele is unfortunately the exception.

The history of technology is in a rather different position in so far as it often is incorporated into history departments, and therefore taught together with economic history as a minor subject for history students. The same applies to Bochum, Darmstadt, Düsseldorf, Hamburg, Hannover and Marburg as well. Specialisation in history of technology is possible for the Ph.D. At Bremen, Köln and Münster history of science or technology is incorporated into departments of philosophy or sociology, but forms a research interest with occasional lectures and courses, rather than a regular course of studies.

6. Institutions. A list of institutions that teach history of medicine or history of science and technology at university level is appended, including only that portion of the teaching staff which meets the formal requirement for university teaching (Habilitation). The category Dozenten is used here in an unusually wide sense to include visiting habilitated lecturers from other institutions. This terminology cum selection criterion is of course rather arbitrary, since there are cases where staff members possess at least the formally recognized equivalent; but of those who lack the formal Habilitation only the professors are included. For example, no member of the teaching staff in history of science at Regensburg possesses the formal 
Habilitation. The Ordinarius professor is listed below, but the university lecturer in history of physics and sociology of science as well as the regular visiting lecturer in the history of medieval and early modern science have both therefore been excluded. It is instructive to add that the latter two positions in history of science have been recently abolished-a symptom of current developments at other institutions as well.

The historical specialities of individual scholars are indicated in brackets if they cannot be inferred from the name of the institute.

Berlin, Freie Universität:

(a) Institut für Geschichte der Medizin, Augustastr. 37, 1000 Berlin 45

Professors: Dr. Johanna Bleker, emeritus Dr. Dr. W. Hoffmann-Axthelm (dentistry), Dr. G. Jüttner (pharmacy), Dr. F. Köcher (ancient oriental medicine), Dr. Dr. R. Winau

Library: Ancient medicine, pharmacology, biologism, pharmacy, dentistry

(b) Osteuropainstitut, Abteilung für Medizin in Osteuropa, Hertastr. 7, 1000 Berlin 37

Professor: Dr. H. Müller-Dietz

Library: Public health and medicine in East European and socialist countries Berlin, Technische Universität:

Institut für Philosophie, Wissenschaftstheorie, Wissenschafts- und Technikgeschichte, Ernst-Reuter-Platz 7, 1000 Berlin 10

Professor: vacant

Dozenten: Prof. Dr. E. Knobloch (mathematics), Prof. Dr. K. Mauel (technology and industrial archeology)

Bochum:

(a) Geographisches Institut, Gebäude NA 4-7, 4630 Bochum

Professor: Dr. Dr. Dr. M. Büttner

Library: Sources for the history of geography before 1800

(b) Lehrstuhl für Wirtschafts- und Technikgeschichte, Gebäude GA 5, 4630 Bochum

Professors: Dr. A. Timm, Dr. W. Weber

Dozent: Dr. J. Braun

\section{Bonn:}

(a) Medizinhistorisches Institut, Sigmund-Freud-Str., 5300 Bonn-Venusberg

Professor: Dr. N. Mani

Dozent: Dr. K. Dieckhöfer (psychiatry)

Library: Ancient and Arabic medicine, psychiatry

(b) Geographisches Institut, Franziskanerstr. 2, 5300 Bonn

Professor: Dr. H. Beck

Dozent: Dr. K. Hoheisel

Braunschweig: Pharmaziegeschichtliches Seminar, Beethovenstr. 55, 3300 Braunschweig

Professors: Dr. Erika Hickel (pharmacy and biology), emeritus Dr. W. Schneider (pharmaceutical chemistry)

Bremen:

(a) Lehrstuhl für Sozial- und Technikgeschichte, Achterstr., 2800 Bremen

Professor: Dr. K. H. Ludwig

(b) Studiengang Sozialwissenschaft, Achterstr., 2800 Bremen

Professor: Dr. H.-D. Bahr (social history of technology)

Darmstadt: Institut für Geschichte, Abteilung Technik- und Wirtschaftsgeschichte, Residenzschloß, 6100 Darmstadt

Professor: Dr. A. Paulinyi 
Dortmund: Abteilung Bauwesen, Lehrstuhl für Baugeschichte, 4600 Dortmund 50 Professor: Dr. L. Suhling (history of technology)

Düsseldorf:

(a) Institut für Geschichte der Medizin, Gebäude 23.12, 4000 Düsseldorf Professor: Dr. H. Schadewaldt

(b) Historisches Seminar, Abteilung für Wirtschaftsgeschichte, Universitätsstr., 4000 Düsseldorf

Professor: Dr. K. Hardach (industrialisation)

Erlangen-Nürnberg: Institut für Geschichte der Medizin, Bismarckstr. 6, 8520 Erlangen

Professor: Dr. H. H. Simmer

Library: Endocrinology and gynaecology, archive for the history of endocrinology

Frankfurt:

(a) Senckenbergisches Institut für Geschichte der Medizin, Theodor-Stern-Kai 7, 6000 Frankfurt 70

Professors: Dr. G. Preiser, Dr. H. Siefert, Dr. O. Winkelmann

(b) Institut für Geschichte der Naturwissenschaften, Myliusstr. 30, 6000 Frankfurt

Professors: Dr. Hertha v. Dechend (ancient cosmology), emeritus Dr. W. Hartner, Dr. W. G. Saltzer, Dr. F. Sezgin (Arabic science)

Library: Astronomy, ancient science and philosophy

Freiburg: Institut für Geschichte der Medizin, Stefan-Meier-Str. 26, 7800 Freiburg Professor: Dr. E. Seidler

Library: History of paediatrics, psychiatry, medical ethics

Giessen: Institut für Geschichte der Medizin, Jheringstr. 6, 6300 Giessen

Professor: Dr. J. Benedum

Göttingen: Institut für Geschichte der Medizin, Wöhlerstr: 9, 3400 Göttingen

Professor: Dr. H. H. Eulner

Library: History of universities, medical topography

Hamburg:

(a) Institut für Geschichte der Medizin, Martinistr. 52, 2000 Hamburg 20

Professors: Dr. H. Grensemann, Dr. C. Lichtenthaeler

Dozent: Dr. H. Rodrega

(b) Institut für Geschichte der Naturwissenschaften, Mathematik und Technik, Bundesstr. 55, 2000 Hamburg 13

Professors: Dr. C. Hünemörder (biology), Dr. W. Schütt (chemistry), Dr. C. J. Scriba (mathematics), Dr. J. Weyer (chemistry); professorship in history of physics vacant

Dozenten: Prof. Dr. K. Garbers (Arabic science), Prof. Dr. H. Schimank (physics and technology)

Library: Astronomy (collection Voss), physics and technology (collection Schimank)

Hannover, Medizinische Hochschule: Seminar für Geschichte der Medizin, Karl-

Wiechert-Allee 9, 3000 Hannover 61

Professor: Dr. F. Hartmann

Library: Medicine of the Enlightenment 
Hannover, Tierärtliche Hochschule: Fachgebiet Geschichte der Veterinärmedizin, Bischofsholer Damm 15, 3000 Hannover 1

Professor: Dr. E. H. Lochmann

Hannover, Universität: Historisches Seminar, Schneiderberg 50, 3000 Hannover Professors: Dr.,K. H. Manegold, Dr. M. Riedel, emeritus Dr. W. Treue

Dozent: Dr. Heide Barmeyer

Heidelberg: Institut für Geschichte der Medizin, Im Neuenheimer Feld 305, 6900 Heidelberg

Professors: Dr. D. v. Engelhardt (sciences), Dr. H. Querner (biology), Dr. Dr. H.

Schipperges

Dozent: Dr. Dorothea Kühn

Kiel: Institut für Geschichte der Medizin und Pharmazie, Brunswiker Str. 2a, 2300

Kiel

Professors: Dr. F. Kudlien, Dr. G. Rudolph

Köln:

(a) Institut für Geschichte der Medizin, Leiblplatz 5, $5000 \mathrm{Köln-Lindenthal}$

Professor: Dr. D. Jetter

Dozent: Prof. Dr. Dr. Marielene Putscher

(b) Philosophisches Seminar, Albertus-Magnus-Platz, 5000 Köln 41

Professor: Dr. Elisabeth Ströker (chemistry, history of scientific method)

Mainz:

(a) Medizinhistorisches Institut, Am Pulverturm 13, 6500 Mainz

Professors: Dr. W. F. Kümmel, Dr. G. Mann (medicine and modern science)

Library: pharmacology, biologism, Darwinism

(b)Arbeitsgruppe für Geschichte der Mathematik und der Naturwissenschaften,

Saarstr. 21, 6500 Mainz

Professors: Dr. F. Krafft, Dr. N. N. Stuloff (mathematics)

Marburg:

(a) Institut für Geschichte der Medizin, Uferstr. 2, 3550 Marburg

Professors: Dr. A. Geus (biology), Dr. H. H. Lauer, Dr. Irmgard Müller (medicine, science and pharmacy)

Library: Medieval medicine, science and technology

(b) Institut für Geschichte der Pharmazie, Roter Graben 10, 3550 Marburg

Professors: Dr. P. Dilg (sciences and pharmacy), Dr. R. Schmitz (sciences and pharmacy)

Library: Archives and library of Joh. Barth. Trommsdorff

(c) Institut für Wirtschafts- und Sozialgeschichte, Krummbogen 28 C, 3550

Marburg

Dozent: Prof. Dr. F. Lerner (technology)

München, Universität:

(a) Institut für Geschichte der Medizin, Lessingstr. 2, 8000 München 2

Professor: Dr. H. Goerke (19th-century and Scandinavian medicine)

Dozenten: Dr. A. Terzioglu (history of hospitals), Prof. Dr. J. H. Wolf (medical iconography)

Library: History of psychiatry

(b) Institut für Geschichte der Naturwissenschaften, Deutsches Museum, 8000

München 22

Professors: emeritus Dr. H. Gericke, Dr. W. Petri (astronomy and oriental natural philsophy), Dr. I. Schneider (science and mathematics), emeritus Dr. K. Vogel (mathematics) 
Dozent: Dr. Brigitte Hoppe (biology, pharmacy and chemistry)

Library: Large library and manuscript collections of the Deutsches Museum

(c) Chemische Institute, Meiserstr. 1-3, 8000 München 2

Dozenten: Dr. O. Krätz (chemistry), Dr. Christa Meyer-Habrich (pharmacy)

München, Technische Universität:

(a) Institut für Geschichte der Medizin und Medizinische Soziologie, Sternwartstr.

2, 8000 München 80

Professors: Dr. G. Pfohl (ancient medicine), Dr. Dr. C. Probst

Library: Medical epigraphy

(b) Institut und Lehrstuhl für die Geschichte der exakten Naturwissenschaften und der Technik, Deutsches Museum, 8000 München 22

Professors: Dr. J.-O. Fleckenstein (sciences and astronomy), Dr. F. Klemm

Dozent: Dr. Karin Figala (pharmacy and alchemy)

Münster:

(a) Institut für Theorie und Geschichte der Medizin, Waldeyerstr. 27, 4400

Münster

Professors: Dr. A. H. Murken (history of hospitals), emeritus Dr. K. E.

Rothschuh (sciences, theoretical medicine), Dr. R. Toellner (medicine 16th to 18th century)

Dozent: Dr. Dietlinde Goltz (medicine and pharmacy)

Library: History of hospitals, physiology, medical theory

(b) Philosophisches Seminar, Johannisstr. 12-20, 4400 Münster

Professor: Dr. U. Hoyer (history of physics)

Oldenburg: Fachbereich Mathematik und Naturwissenschaften, Ammerländer

Heerstr. 67-99, 2900 Oldenburg

Professor: Dr. M. Folkerts (mathematics)

Regensburg: Lehrstuhl für allgemeine Wissenschaftsgeschichte, Gebäude PT, 8400 Regensburg

Professor: Dr. I. Toth (mathematics)

Stuttgart: Lehrstuhl für Geschichte der Naturwissenschaften und Technik, Friedrichstr. 10, 7000 Stuttgart

Professor: Dr. A. Hermann (physics, science policy, organisation of science)

Dozent: Prof. A. Kleinert

\section{Tübingen:}

(a) Institut für Geschichte der Medizin, Denzenberghalde 12, 7400 Tübingen

Professor: Dr. G. Fichtner

(b) Lehrstuhl für Geschichte der Naturwissenschaften, Köstlinstr. 6, 7400

Tübingen

Professors: Dr. F. Rex (ancient science, physics, alchemy), Dr. M. Schramm (physics and astronomy)

Würzburg: Institut für Geschichte der Medizin, Koellikerstr. 6, 8700 Würzburg

Professor: Dr. Dr. G. Keil

Dozent: Dr. W. F. Daems

Library: Medieval, Asian and Oriental medicine

7. Tabular sumımary. I conclude this survey with a talle indicating the number of teaching staff at each institution and the courses that they offer. Additional remarks are given where necessary. 
University

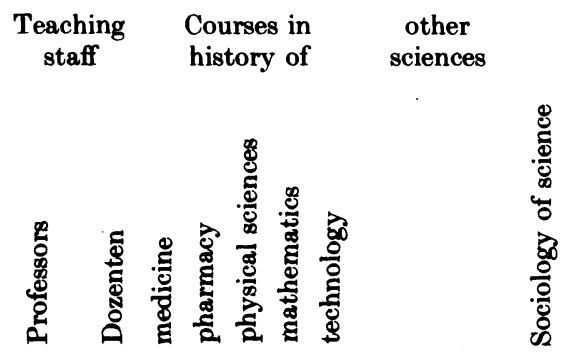

Remarks on curricula

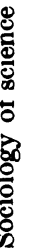

\begin{tabular}{|c|c|c|c|c|c|c|c|}
\hline \\
\hline \multirow{2}{*}{$\begin{array}{l}\text { History of medicine } \\
\text { Berlin, FU }\end{array}$} & (a) & 4 & & $x$ & $x$ & & dentistry \\
\hline & (b) & 1 & & $x$ & & & \\
\hline Bonn & (a) & 1 & 1 & $x$ & & & \\
\hline Düsseldorf & (a) & 1 & & $x$ & & & \\
\hline Erlangen-Nürmberg & & 1 & & $x$ & & & \\
\hline Frankfurt & (a) & 3 & & $x$ & & & \\
\hline Freiburg & & 1 & & $x$ & & & \\
\hline Giessen & & 1 & & $x$ & & & \\
\hline Göttingen & & 1 & & $x$ & & & \\
\hline Hamburg & (a) & 2 & 1 & $x$ & & & \\
\hline Hannover, Med. H. & & 1 & & $x$ & & & \\
\hline Veter. $\mathbf{H}$. & & 1 & & & & & $\begin{array}{l}\text { veterinary } \\
\text { sciences }\end{array}$ \\
\hline Heidelberg & & 3 & 1 & $x$ & & $x$ & biology \\
\hline Kiel & & 2 & & $x$ & & & \\
\hline Köln & (a) & 1 & 1 & $x$ & & & \\
\hline Mainz & (a) & 2 & & $x$ & & $x$ & biology \\
\hline Marburg & (a) & 3 & & $x$ & $x$ & $x$ & biology \\
\hline München, Univ. & (a) & 1 & 2 & $x$ & & & \\
\hline TU & (a) & 2 & & $x$ & & & \\
\hline Münster & (a) & 2 & 1 & $x$ & $x$ & & \\
\hline Tübingen & (a) & 1 & & $x$ & & & \\
\hline Würzburg & & 1 & 1 & $x$ & $x$ & & \\
\hline
\end{tabular}

Interdisciplinary courses on the history of endocrinology

Compulsory for students of veterinary medicine

Option for students of biology
History of science and technology

Berlin, TU

Bochum

Bonn

Braunschweig

Dortmund

Frankfurt

Hamburg

Mainz

(b) 2

(b) 2

Marburg

München, Univ.

TU

Oldenburg

(b)

(c)

2

(b) 21

Regensburg

Stuttgart

$\begin{array}{lll}\text { (a) } & 1 & 2 \\ \text { (b) } & 1 & 1 \\ & 1 & \\ & 1 & \\ \text { (b) } & 3 & \\ \text { (b) } & 4 & 2\end{array}$
1

$\begin{array}{cccc}\times & \times & \times & \\ \times & & & \begin{array}{l}\text { geography } \\ \text { geography } \\ \text { biology }\end{array} \\ \times & & & \\ \times & & & \\ \times & \times & \times & \text { biology }\end{array}$

$\times$

M.A. course in history of science Option for students of geography eography biology
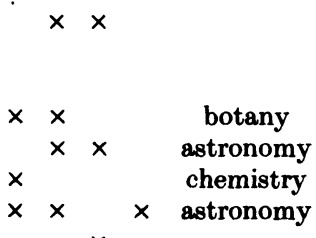
$\times$ $\times \times$ $\times x$
Compulsory for student teachers in sciences; option for students of mathematics, physics and biology Option for students of mathematics and for student teachers in mathematics, physics and chemistry Option for students of biology

Compulsory for students of mathematics

$\times$ M.A. courses in history of science; courses for students of philosophy

$\times$ M.A. course in history of science; option for students of history and for students of electrical engineering

Tübingen 
University

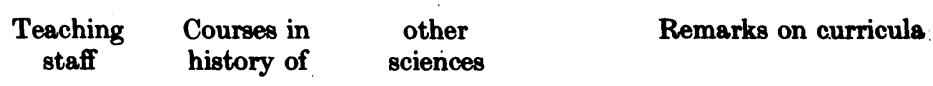

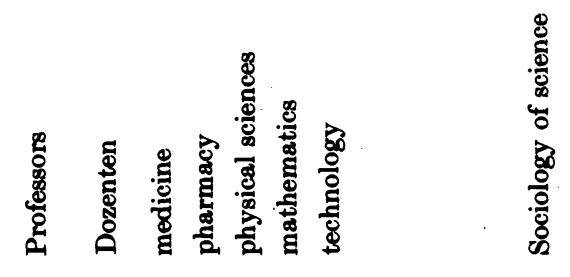

History of science or technology within history or social sciences departments

Bochum

Bremen

Darmstadt

Düsseldorf

Hannover, Univ.

Köln

Marburg

Münster (b) 21

(b) 2

(b) 1

(b) 1

(b) 1

(c) 1

(b) 1

\section{$x$}

$x$

$x$

$x$

$x$

$x$
Option for students of history

$\times$ Option for social science students Option for students of history Option for students of history Option for students of history Courses for students of philosophy Courses for students of history Option for students of philosophy 